\title{
STATISTICAL ANALYSIS OF THE RECEIVABLES OF ENTERPRISES OF HOUSING AND COMMUNAL SERVICES: ACCOUNTING SUPPORT
}

\author{
Petro Kutsyk ${ }^{1}$
}

\begin{abstract}
The branch characteristics of activity of the enterprises of housing and communal services are defined with features of management of receivables: its absence of alternative concerning partially rendered services to consumers that would directly influence reduction of incomes of the enterprise of housing and communal services; its impossibility of resale of services, lack of clear control over the quality of services provided and its price, which leads to dissatisfaction with the social needs of the population; its lack of flexible discounts for honest payers of housing and communal services. The analysis of the structure of receivables of the population for the consumed housing and communal services of the enterprises of the Lviv region during April-August 2020 is carried out. It is established that the use of inefficient methods of housing management leads to low payment discipline of buyers, which contributes to the deterioration of the financial condition of the industry as a whole. Therefore, methods of accelerating the payment of receivables with appropriate reporting on the quality of services provided should be actively used. The dynamics of the amount of funds for which agreements on debt restructuring for housing and communal services have been concluded, and the amount repaid by consumers-debtors indicates increased activities on concluding contracts and gradual repayment of debts by consumers.

In case of overdue receivables for housing and communal services, the consumer should be reminded of the need to pay the debt in different ways. These are in the form of a re-receipt, correspondent (send by registered mail on demand), SMS, or call, or direct visit of the housing and communal services department representative to the service object, and finding out the cause of existing receivables, the order of criteria for their classification into doubtful and bad types of receivables. The purpose of the research is to identify sectorial characteristics of housing and communal services, which determine the features of receivables management and improve the methodology of statistical analysis of receivables to identify causes of late payment of housing and communal services and ways to motivate consumers to repay debts. Methodology. The method of statistical analysis of receivables is developed to be carried out in three stages: analysis of the structure of receivables; analysis of the dynamics of receivables for communal services; analysis of the effectiveness of receivables restructuring. Results. The following stages of statistical analysis of receivables for housing and communal services are offered. Analysis of the structure of receivables to determine the types of housing and communal services for which we observe the largest and smallest share in total is proposed. Analysis of the dynamics of receivables for communal services to determine trends in indicators in the regional aspect is suggested. Analysis of the effectiveness of the restructuring receivables (provides for the calculation of the increase in the number of agreements on debt restructuring and assessment in the dynamics of repayment of these receivables) is proffered. Practical implications. We identified effective management methods of receivables of housing and communal services that improves the financial condition of the industry as a whole. Value/originality. The statistical analysis of the receivables of enterprise of housing and communal services has been further developed.
\end{abstract}

Key words: receivables, statistical analysis, restructuring, housing and communal services department, accounting.

JEL Classification: G18, H32, M21

Corresponding author:

${ }^{1}$ Lviv University of Trade and Economics, Ukraine.

E-mail: kutsykpetro@gmail.com

ORCID: http://orcid.org/0000-0001-5795-9704

ResearcherID: G-9204-2019 


\section{Introduction}

The activity of housing and communal services department is carried out in conditions of low contractual discipline, which leads to significant amounts of doubtful and bad receivables. At the same time, a certain part of consumers is dissatisfied with the existing discrepancy between the size of tariffs and the quality of services provided. Therefore, the calculation of the current calculation of the cost of services provided by the management of housing and communal services requires greater substantiation, publication and bringing to the notice of consumers. The appropriate adjustments should be made in case of unreasonable overestimation of certain articles. The research of statistical indicators of the structure and dynamics of existing receivables in the regional aspect will identify regions with or without violations, as well as positive or negative trends in changes in payment discipline by consumers of housing and communal services.

The lack of effective methodological approaches to debt management for housing and communal services necessitates the development of methodological support for statistical analysis of receivables of housing and communal services, which will improve the liquidity and solvency of enterprises in the industry.

\section{Brief literature review}

The receivables that are in doubt should be disclosed (Chyzhevska et al., 2019). In order for receivables to be transparent, it is necessary to disclose reports in more detail, reflecting in the reporting lines the amount of receivables in terms of taxes and types of receivables and other information on receivables and its management, because there are debts that are actually bad.

The financial statements are not enough to manage receivables. The qualitative and quantitative data complement and support each other, they must be considered simultaneously by the users of the annual report so that they can make the right decisions.

The qualitative and quantitative data complement and support each other, it must be considered simultaneously by the users of the annual report so that they can make the right decisions (Kubašćíková et al., 2019). The investors and other users of the annual reports are encouraged to research the descriptions together with individual financial situations and other sources of information to get a full picture of the possible future development of the company's financial performance. This, in turn, would promote their ability to make the right investment decisions and allow them to assess the value of their funds.

The causes of doubtful and bad receivables are due to the peculiarities of housing and communal services department, which affect the nature of socio-economic relations in the industry such as:

1. Continuity of the process of providing and consuming services.

2. Social orientation (significance) of services.

3. No alternative to the services provided.

4. Inseparability of the process of providing and consuming services.

5. The dependence of production and consuming services.

6. Social response to the results of service providers.

7. The production nature of the formation of prices and tariffs for services.

8. Intangible nature of services provided (intangibility, impossibility of accumulation (tare) and resale) (Holovchenko et al., 2017).

We believe that the main characteristics of enterprises of housing and communal services that directly affect the management of receivables are:

- The lack of alternatives to partially provide services to consumers, which would directly affect the reduction of income of enterprises of housing and communal services.

- Impossibility of resale of services, lack of clear control over the quality of services provided and price, which leads to dissatisfaction with the social needs of the population, lack of flexible discounts for honest payers of housing and communal services.

The economic component of the agglomeration effect, which forms the competitive advantages of housing and communal services department in urban agglomerations, includes:

- ensuring the profitability of enterprises in the industry;

- reducing accounts payable and receivable;

- optimizing (saving) management costs and reducing management risks (and, in turn, costs associated with its elimination, minimization, localization or prevention) by reducing the management staff (Hradoboieva et al., 2015).

The level of payment for services by the population; the level of reimbursement of expenses 
for the production of services; the average cost of services ensures the break-even operation of enterprises of housing and communal services (Kipenko et al., 2014). That is, the presence or absence of receivables significantly determines the further vector of work with consumers to encourage timely payment of debts.

The cause of receivables and payables in the housing sector are a number of factors (Havrylenko et al., 2014). It is the current significant debt in Ukraine with the payment of wages and other cash payments to the population. In this situation, people are physically unable to pay exorbitant prices for energy, housing and communal services. However, tariffs for housing and communal services must be economically justified, because both low or high prices and tariffs for services lead to destabilization of the housing and communal services department. In the first case, there is an aging of fixed assets and the impossibility of technological renewal of the industry, which increases the loss of energy, water and other resources and, accordingly, creates conditions for increasing the cost of works and services of enterprises of housing and communal services. Therefore, in order to solve the problems of the industry, it is necessary to attract additional financial and material resources. At the same time, the unprofitability of enterprises of housing and communal services, the lack of sources of financing the costs of upgrading its material and technical base does not make it possible to attract investment in the industry, introduce modern production technologies and save resources, as well as obtain loans.

Each enterprise must form a set of analytical indicators guided by its own information needs. As a rule, when analyzing receivables, analysts of enterprises calculate the following indicators in Ukraine:

- its total volume;

- the amount of overdue receivables;

- timeliness of payments;

- its actual reversibility (general and in the context of each client);

- the dynamics of its repayment;

- the average period of deferred payments;

- the average repayment period of the deferral;

- the dynamics of working capital, etc.

The calculation of these indicators makes it possible to control the movement of current funds and maintain the minimum required level of cash. Often, business leaders cannot obtain the necessary information on the maturity of receivables, because the available information systems cannot ensure the formation of a report. In addition to the amount and timing of receivables, it is necessary to control the order of payments, receipts for each group of services and for each debtor, the emergence of a critical level of debt on it (Fedorchenko et al., 2015). The control of doubtful and bad debts should be carried out for each consumer who did not pay on time for the received housing and communal services.

\section{Results}

The method of statistical analysis of receivables allows establishing patterns of state and development of housing and communal services department. The following stages of statistical analysis of receivables for housing and communal services are offered:

1. Analysis of the structure of receivable.

2. Analysis of the dynamics of receivables for communal services.

3. Analysis of the effectiveness of receivables restructuring (provides the calculation of the increase in the number of agreements on debt restructuring and assessment in the dynamics of repayment of these receivables).

The first stage is "Analysis of the structure of receivable". We consider the method of statistical analysis of the structure of receivable on Lviv region during April-August 2020; the calculated indicators are given in Table 1.

In the total amount of receivables of the population for consumed housing and communal services of enterprises of housing and communal services of Lviv region during April-August 2020, the largest specific weight on April 1, 2020 and on August 1, 2020 is district heating and hot water supply (65.84 \% and $53.66 \%$ respectively). Moreover, there is a decrease in debt by 188.4 million UAH or $35.49 \%$ for April-August 2020 , and there is a decrease by 12.18 points of the structure in the share of consumer debt for district heating and hot water supply in the total amount of communal services. The debts for communal services have the lowest share, in terms the removal of household waste, in particular, on April 1, 2020 - $3.15 \%$, and on August 1, $2020-4.59 \%$. However, the total amount of unpaid payments for garbage removal in Lviv region increased by 3.90 million UAH or by $15.35 \%$. 
Table 1

Methods of statistical analysis of the structure of receivable of the population for consumed housing and communal services of enterprises of housing and communal services of Lviv region during April-August 2020

\begin{tabular}{|c|l|c|c|c|c|c|c|c|}
\hline \multirow{2}{*}{ No } & \multicolumn{1}{|c|}{ Article } & $\begin{array}{c}\text { Amount } \\
\text { in millions } \\
\text { UAH }\end{array}$ & $\begin{array}{c}\text { Specific } \\
\text { weight, \% }\end{array}$ & $\begin{array}{c}\text { Amount } \\
\text { in millions } \\
\text { UAH }\end{array}$ & $\begin{array}{c}\text { Specific } \\
\text { weight, \% }\end{array}$ & $\begin{array}{c}\text { Absolute } \\
\text { deviation } \\
\text { in millions } \\
\text { UAH }\end{array}$ & $\begin{array}{c}\text { Delative } \\
\text { Reviation, \% }\end{array}$ & $\begin{array}{c}\text { Deviations } \\
\text { in the points } \\
\text { of the } \\
\text { structure }\end{array}$ \\
\hline 1 & $\begin{array}{l}\text { District heating } \\
\text { and hot water } \\
\text { supply }\end{array}$ & 530.9 & 65.84 & 342.5 & 53.66 & -188.4 & -35.49 & -12.18 \\
\hline 2 & $\begin{array}{l}\text { Water supply and } \\
\text { drainage }\end{array}$ & 115.3 & 14.30 & 132.4 & 20.74 & 17.1 & 14,83 & 6.44 \\
\hline 3 & $\begin{array}{l}\text { Maintenance of } \\
\text { buildings and } \\
\text { adjacent territory }\end{array}$ & 134.7 & 16.71 & 134.1 & 21.01 & -0.60 & -0.45 & 4.30 \\
\hline 4 & $\begin{array}{l}\text { Removal of } \\
\text { household waste }\end{array}$ & 25.4 & 3.15 & 29.3 & 4.59 & 3,90 & 15.35 & 1.44 \\
\hline
\end{tabular}

Source: Ministerstvo rozvytku hromad ta terytorii Ukrainy

The total amount of consumer debt for water supply and drainage in Lviv region increased by 17.1 million UAH or $14.83 \%$. The debts of consumers for services related to the maintenance of buildings and adjacent territory decreased by 0.6 million UAH or $0.45 \%$.

The second stage is "Analysis of the dynamics of receivables for communal services". In general, during January-August 2020, the debt for consumed housing and communal services in Ukraine decreased by 1597.4 million UAH or $5.24 \%$. This is a positive trend in such regions as Vinnytsia, Dnipropetrovsk, Zhytomyr, Zaporizhzhia, IvanoFrankivsk, Kyiv, Lviv, Mykolaiv, Odesa, Poltava, Rivne, Sumy, Ternopil, Kherson, Khmelnytskyi, Cherkasy, Chernivtsi, Chernihiv, and the city of Kyiv. In other regions, there is a deterioration of payment discipline.

The dynamics of consumer debt for communal services of Lviv region during 7 months of 2020 is shown in Figure 1.

During 7 months of 2020, the largest amount of consumer debt for housing and communal services in Lviv region falls on February 1, 2020, and the lowest - on August 1, 2020, and starting from April 2020 there is a positive trend towards a gradual decrease in debt.

The use of inefficient management methods of housing and communal services department leads to low payment discipline of buyers, which contributes to the deterioration of the financial condition of the industry as a whole. Therefore, methods of accelerating the payment of receivables with appropriate reporting on the quality of services provided should be actively used.

The third stage "Analysis of the effectiveness of receivables restructuring". In order to assess how effectively the debt restructuring for housing and communal services was carried out, it is necessary to analyze how the increase in the concluded restructuring agreements affected the amount of receivables repayment. The dynamics of growth in the number of agreements on debt restructuring and the dynamics of repayment of this receivable in Ukraine as a whole are given in Table 2.

The dynamics of the amount of funds, for which agreements on debt restructuring for housing and communal services have been concluded, and the amount repaid by consumers-debtors testify to the revival of activities on concluding contracts and gradual repayment of debts by consumers.

In case of overdue receivables for housing and communal services, the consumer should be reminded of the need to pay the debt in different ways. These are in the form of a re-receipt, correspondent (send by registered mail on demand), SMS, or call, or direct visit of the housing and communal services department representative to the service object, and finding out the cause of existing receivables, the order of criteria for their classification into doubtful and bad types of receivables. 


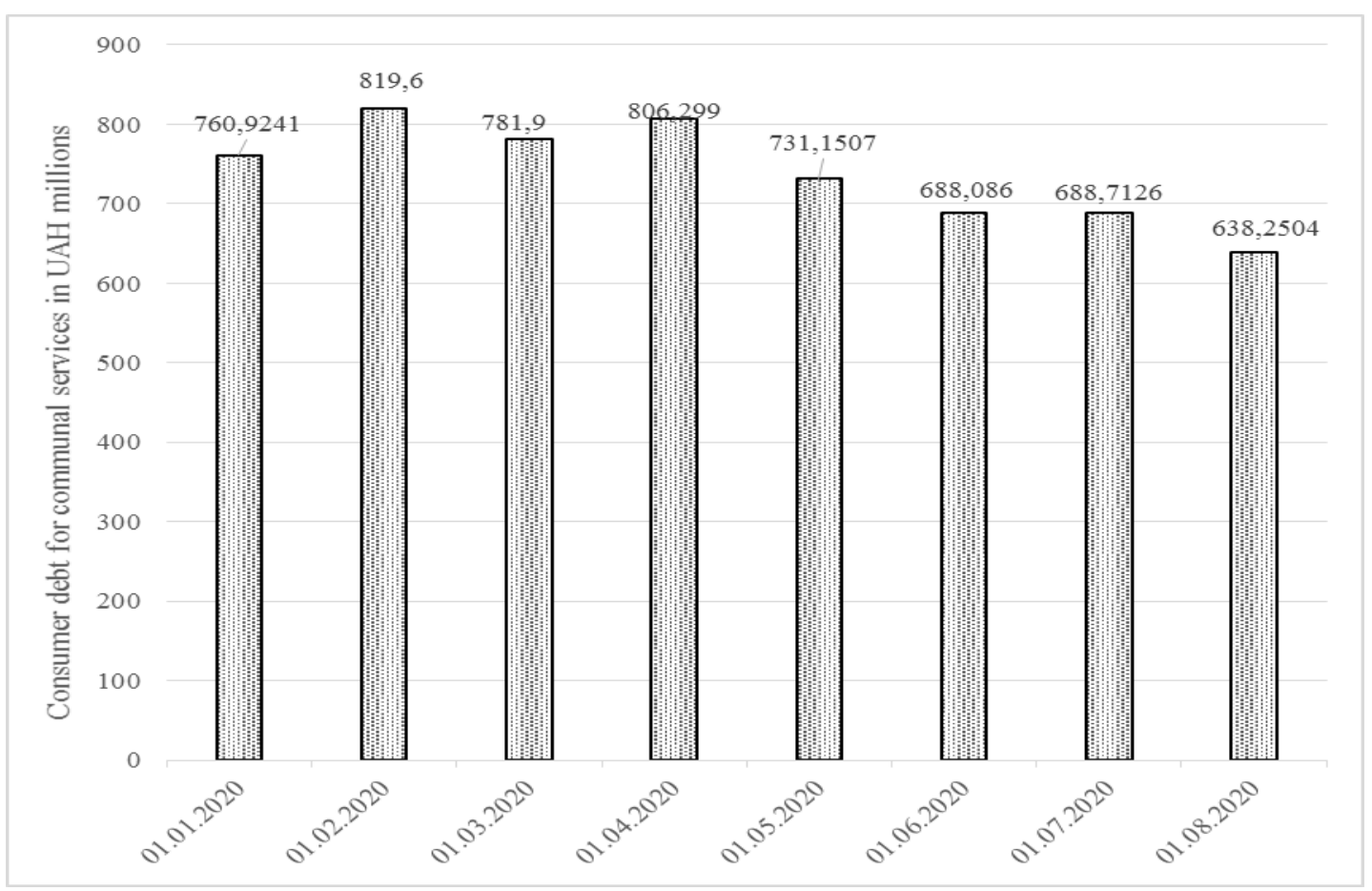

Figure 1. The dynamics of consumer debt for communal services of Lviv region during 7 months of 2020

Source: State Statistics Service of Ukraine

Table 2

Dynamics of growth in the number of agreements on debt restructuring and the dynamics of repayment of this receivable in Ukraine as a whole during January-July 2020

\begin{tabular}{|c|c|c|c|c|}
\hline Month & $\begin{array}{c}\text { Number of concluded } \\
\text { agreements, units }\end{array}$ & $\begin{array}{c}\text { Amount of restructured } \\
\text { debt for housing and } \\
\text { communal services in } \\
\text { thousand UAH }\end{array}$ & $\begin{array}{c}\text { Amount of repayment } \\
\text { of restructured debt for } \\
\text { housing and communal } \\
\text { services in thousand UAH }\end{array}$ & $\begin{array}{c}\text { Repayment of restructured } \\
\text { debt for housing and } \\
\text { communal services, \% }\end{array}$ \\
\hline January & 4933 & 38587.9 & 37359.7 & 96.82 \\
\hline February & 5532 & 59005.5 & 24248.4 & 41.10 \\
\hline March & 3539 & 151470.4 & 107865.7 & 71.21 \\
\hline April & 1558 & 8333.2 & 18072.4 & 216.87 \\
\hline May & 2049 & 11998.3 & 18597.9 & 155.00 \\
\hline June & 3841 & 28949.1 & 19507.5 & 67.39 \\
\hline July & 4631 & 35028.7 & 21524.7 & 61.45 \\
\hline
\end{tabular}

Source: Ministerstvo rozvytku hromad ta terytorii Ukrainy

\section{Conclusions}

The following stages of statistical analysis of receivables for housing and communal services are offered. Analysis of the structure of receivables to determine the types of housing and communal services for which we observe the largest and smallest share in total is proposed. Analysis of the dynamics of receivables for communal services to determine trends in indicators in the regional aspect is suggested. Analysis of the effectiveness of the restructuring receivables (provides for the calculation of the increase in the number of agreements on debt restructuring and assessment in the dynamics of repayment of these receivables) is proffered.

The use of inefficient management methods of housing and communal services department leads to low payment discipline of buyers, which contributes to the deterioration of the financial condition of the industry as a whole. Therefore, you should actively use reminder methods that will speed up the payment of receivables with 
appropriate reporting on the quality of services provided. These are in the form of a re-receipt, correspondent (send by registered mail on demand), SMS, or call, or direct visit of the housing and communal services department representative to the service object, and finding out the cause of existing receivables, the order of criteria for their classification into doubtful and bad types of receivables.
The statistical analysis of the dynamics of the amount of funds for which agreements on debt restructuring for housing and communal services and the amount repaid by consumers-debtors shows the effectiveness of this method of debt management.

The prospects for further research are the development of measures to improve the payment discipline of consumers of housing and communal services.

\section{References:}

Kubaščíková, Z., Tumpach, M., Juhaszova, Z., Turebekova, B., \& Saparbayeva, S. (2019). Contextual Non-financial Information Analysis of Annual Reports. - Registrovaný vo: Web of Science. In European Financial Systems 2019. International Scientific Conference. European Financial Systems 2019: Proceedings of the 16th International Conference, June 24-25, 2019, Brno, Czech Republic. Brno: Masaryk University, pp. 334-344.

Brazhnikova, L. M. (2012). Upravlinnia vytratamy yak factor pidvyshchennia efektyvnosti diialnosti pidpryiemstva $\mathrm{ZhKH}$ [Cost management as a factor in improving the efficiency of diagnostics of housing and communal services]. Naukovyi visnyk Chernihivskoho derzhavnoho instytutu ekonomiky i upravlinnia. Seriia 1: Ekonomika, vol. 1, pp. 164-171.

Havrylenko, V. (2014). Upravlinnia debitorskoiu ta kredytorskoiu zaborhovanistiu zhytlovokomunalhono hospodarstva rehionu [Management of receivables and payables of housing and communal services of the region]. Zbirnyk naukovykh prac Cherkaskoho derzhavnoho tekhnolohichnoho universytetu. Serija: Ekonomichni nauky, vol. 36(3), pp. 18-22.

Holovchenko, O. O., \& Holovchenko, N. Yu. (2017). Haluzevi kharakterystykyZhKH, shcho pryntsypovo vplyvaiut na pobudovu informatsiinykh system obliku ta kontroliu [Sectoral characteristics of housing and communal services, which fundamentally influence the construction of information systems in the form and control]. Naukovi praci Kirovoghradsjkogho NTU. Ekonomichni nauky, vol. 31, pp. 189-196.

Hrabodoieva, Ye. (2015). Zhytlovo-komunalne hospodarstvo miskykh ahlomeratsii: osoblyvosti funktsionuvannia ta vektory rozvytku [Housing and communal services of urban agglomerations: features of functioning and vector of development]. Skhid, vol. 5, pp. 18-22.

Kipenko, M. F. (2014). Kryterii otsiniuvannia rezultativ reformuvannia zhytlovo-komunalnoho hospodarstva Ukrainy na osnovi pokaznykiv ta indykatoriv zvitnosti [Criteria for evaluating the results of reforming the housing and communal services of Ukraine on the basis of indicators and performance indicators]. Ekonomika ta derzhava, vol. 3, pp. 135-138.

Stan oplaty naselenniam zhytlovo-komunalnykh posluh (bez urakhuvannia hazu ta elektroenerhii). Ministerstvo rozvytku hromad ta terytorii Ukrainy. Available at: https://www.minregion.gov.ua/ napryamki-diyalnosti/zhkh/tarif/stan-oplati-naselennyam-zhitlovo-komunalnih-poslug-za-2015-rik/ stanom-na-1-serpnya-2020-roku (accessed 01 October 2020).

Stan pohashennia naselenniam restrukturyzovanoi zaborhovanosti za zhytlovo-komunalni posluhy. Derzhavna sluzhba statystyky Ukrainy. Available at: URL: http://www.ukrstat.gov.ua (accessed 01 October 2020).

Fedorchenko, O. Ye. (2015). Aktualjni problemy upravlinnja debitorsjkoju zaborghovanistju na pidpryjemstvi [Actual problems of receivables management at the enterprise]. Investyciji: praktyka ta dosvid, vol. 21, pp. 60-63.

Chyzhevska, L. V., Koretska, Yu. I., \& Palamarchuk, A. S. (2019). Transparentnist finansovoi zvitnosti, skladenoi za MSFZ yak instrument antykoruptsiinoi diialnosti v Ukraini [Transparency of financial reporting, a component for MSFZ as a tool for anti-corruption diagnostics in Ukraine]. Mizhnarodnyi zbirnyk naukovykh prats na bazi Derzhavnoho universytetu Zhytomyrska politekhnika" "Problemy teorii ta metodolohii bukhhalterskoho obliku, kontroliu ta analizyu", vol. 1, pp. 110-115. 